\title{
Hemodynamics and renal
}

function during administration

of low-dose dopamine in

severely ill patients

Intensive Care Unit, Discipline of Anesthesiology, Pain and Intensive Care, Universidade Federal de São Paulo, São Paulo, Brazil

\section{. . . . . . INTRGODUCTIOH}

Dopamine is an endogenous catecholamine, and is the immediate metabolite of norepinephrine and epinephrine. At low concentrations of 0.2 to $5 \mu \mathrm{g} / \mathrm{kg} / \mathrm{min}$, dopamine acts on two populations of dopaminergic receptors (DA), called the DA1 and DA2 receptors. DA1 receptors are post-synaptic and are located in the smooth muscle cells of renal, mesenteric and coronary gastric vessels and in hepatic arteries. ${ }^{1}$ DA2 receptors are pre-synaptic and are located in the adrenal medulla and sympathetic nerve endings. ${ }^{1}$ Binding of dopamine to these two specific receptors causes arterial vasodilation, ${ }^{2}$ as well as increased glomerular filtration, renal blood flow and fractional sodium excretion. ${ }^{3,4}$

Acute renal failure is relatively frequent among severely ill patients. Although the introduction of biocompatible membranes into hemodialysis has contributed towards increasing the survival rate of acute renal failure patients, this condition is associated with poor prognosis, especially when associated with multiple organ dysfunction. ${ }^{2}$

The term "dopaminergic effect" is used to refer to stimulus of the dopaminergic receptors (and possibly the beta receptor), without changes in the arterial pressure. ${ }^{5}$ This effect is achieved with dopamine doses of less than $3 \mu \mathrm{g} / \mathrm{kg} / \mathrm{min}$ (called "dopaminergic doses"). Many believe that the infusion of $2 \mu \mathrm{g} / \mathrm{kg} /$ min of dopamine may benefit renal function, thereby increasing electrolyte excretion and urine output. ${ }^{5-7}$ Such opinions have led to the routine use of low-dose dopamine (LDD) in situations with the risk of renal failure. Indeed, because of its hemodynamic and renal effects, LDD has been used in severely ill patients in an effort to minimize renal dysfunction.

Notwithstanding this recommendation, doubts remain concerning the beneficial effects of this procedure. ${ }^{3,6,8-11}$ Studies with animals $s^{12}$ and acute renal failure patients $s^{8,9,13-17}$ have not shown evidence that LDD maintained or improved renal function.

Thus, if proven inadequate, continued injection of LDD would result only in potential additional medical treatment, ${ }^{18}$ thereby increasing the costs. The objective of the present study was to evaluate the effect of the continuous injection of $2 \mu \mathrm{g} / \mathrm{kg} / \mathrm{min}$ of dopamine on the systemic hemodynamics and renal function of patients under intensive care.

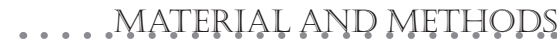

This study was a non-randomized, open, prospective clinical trial, conducted within a surgical intensive care unit of a tertiary university hospital: Hospital São Paulo, Universidade Federal de São Paulo - Escola Paulista de Medicina (Unifesp - EPM). Following approval of the research protocol by the hospital's Ethics Committee, 22 patients admitted to the intensive care unit were included in the trial after giving their informed consent. The inclusion criteria were that they should be aged over 18 and present hemodynamic stability. Patients were excluded if they were currently using vasoactive drugs or had previously been treated with dopamine, if they presented coronary disease or acute/chronic renal failure, and if there was no indication for bladder catheterization.
- Cláudia Nathalie Pereira

- Flávia Ribeiro Machado

- Hélio Penna Guimarães

- Ana Paula Resque Senna

- José Luiz Gomes do Amaral

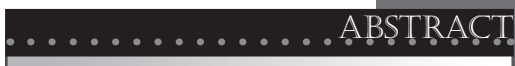

CONTEXT: Although a large number of studies have been performed regarding the renal and hemodynamic effects of the infusion of low-dose hemodynamic effects of the infusion of low-dose
dopamine (LDD) in severely ill patients, there is still controversy on this subject.

OBJECTIVE: To evaluate the effects of dopamine (2 $\mu \mathrm{g} / \mathrm{kg} / \mathrm{min}$ ) on systemic hemodynamics (lowest mean arterial pressure, MAP, highest heart rate, $H R$, central venous pressure, CVP), creatinine clearance (CLcr), diuresis and fractional sodium clearance $(\mathrm{CLCr})$, diure
excretion $\left(\mathrm{FENa}^{+}\right)$.

TYPE OF STUDY: A non-randomized, open, prospective clinical trial.

SETTING: An intensive care unit in a tertiary university hospital.

PARTICIPANTS: 22 patients with hemodynamic stability admitted to the intensive care unit.

PROCEDURES: Patients were submitted to three two-hour periods: without dopamine (P1), with dopamine (P2) and without dopamine (P3).

MAIN MEASUREMENTS: The abovementioned variables were measured during each period. CLcr was assessed based upon the formula $\mathrm{U} \times \mathrm{V} / \mathrm{P}$, where $U$ is urinary creatinine $(\mathrm{mg} / \mathrm{dll}), \mathrm{V}$ is diuresis in $\mathrm{ml} / \mathrm{min}$ and $\mathrm{P}$ is serum creatinine $(\mathrm{mg} / \mathrm{dll})$. FENa ${ }^{+}$ in $\mathrm{ml} / \mathrm{min}$ and $\mathrm{P}$ is serum creatinine $(\mathrm{mg} / \mathrm{dl})$. $\mathrm{FENa}^{+}$ sodium $(\mathrm{mEq} / \mathrm{l}) \times \mathrm{P} /$ plasma sodium $(\mathrm{mEq} / \mathrm{l}) \times$ $\mathrm{U}) \times 100$. Results were presented as mean and standard deviation. The Student $t$ test was used and results were considered significant if $p$ was less than 0.05 .

RESULTS: Twelve patients (seven males and five females) were included, with a mean age of 55.45 years. There was no significant variation in MAP, HR, CVP, CLcr or FENa+ with a dopamine dose of $2 \mu \mathrm{g} / \mathrm{kg} / \mathrm{min}$. On the other hand, diuresis significantly increased during $\mathrm{P} 2$, from 225.4 to $333.9 \mathrm{ml}$

CONCLUSION: Infusion of $2 \mu \mathrm{g} / \mathrm{kg} / \mathrm{min}$ of dopamine for 2 hours increases diuresis. At the doses studied, dopamine does not induce significant alterations in MAP, HR, CVP, CLcr and FENa+.

KEY WORDS: Dopamine. Hemodynamic processes. Intensive care units. Diuresis. Diuretics. 
The patients included were classified according to the Acute Physiology and Chronic Health Evaluation II (APACHE II) disease severity system. ${ }^{19}$ For the duration of the study, the crystalloid infusion and ventilation support remained unchanged and no new drugs were administered.

Patients were evaluated over a six-hour pe- riod divided into three periods of two hours. In the first period (P1), saline solution was infused at a volume corresponding to what would be needed for infusing $2 \mu \mathrm{g} / \mathrm{kg} / \mathrm{min}$ of dopamine. In the second period (P2), $2 \mu \mathrm{g} / \mathrm{kg} / \mathrm{min}$ of dopamine were administered. In the third period (P3), saline infusion was resumed.

At the end of each period, diuresis (UV)

\begin{tabular}{lc} 
& $\begin{array}{c}\text { Table 1. Anthropometric data of 22 patients admitted } \\
\text { in a surgical intensive care unit in São Paulo }\end{array}$ \\
\hline Variable & Value \\
\hline Age (years) & $55.45 \pm 22.69(16-89)$ \\
\hline Weight $(\mathrm{kg})$ & $69.48 \pm 12.58(50-95)$ \\
\hline Height $(\mathrm{cm})$ & $1.68 \pm 0.08(1.53-1.80)$ \\
\hline Gender $($ male/female) & $9 / 13$ \\
\hline
\end{tabular}

Results are expressed in mean \pm standard deviation (range).

Table 2. Classification of the disease severity (according to Acute Physiology and Chronic Heath Evaluation II, APACHE II) of 22 patients admitted in a surgical intensive care unit in São Paulo

\begin{tabular}{cc} 
APACHE II & Patients \\
\hline$<15$ & 4 \\
$15-25$ & 13 \\
\hline 25 & 5 \\
\hline
\end{tabular}

Table 3. Individual diagnosis upon admission at intensive care unit of 22 patients in São Paulo

\begin{tabular}{|cc}
\hline Patients & Diagnosis \\
\hline AWG & Esophagus carcinoma (PO) \\
\hline LTC & Politraumatism \\
\hline NSA & Politraumatism \\
\hline AO & Status epilepticus \\
\hline JRP & Retroperitoneal abcess (PO) \\
\hline EMG & Meningioma (PO) \\
\hline ONO & Medular compression (PO) \\
\hline AR & Acute pancreatitis \\
\hline AV & Femur fracture (PO) \\
\hline SBR & Medular compression (PO) \\
\hline EM & Aortic aneurism (PO) \\
\hline JG & Myasthenia gravis \\
\hline WO & Pulmonary metastatic cancer (PO) \\
\hline ECS & Cerebral aneurism (PO) \\
\hline MO & Extradural hematoma (PO) \\
\hline AGA & Hernia hiatal (PO) \\
\hline LAP & Pneumonia \\
\hline JB & Ectopic pregnancy (PO) \\
\hline RZM & Esophagus carcinoma (PO) \\
\hline GCA & Medular compression (PO) \\
\hline FCB & Rip fracture (PO) \\
\hline MHA & \\
\hline & \\
\hline &
\end{tabular}

$P O=$ admission at immediate postoperative period.

was established and a sample for urinary sodium $\left(\mathrm{UNa}^{+}-\mathrm{mmol} / \mathrm{l}\right)$ and urinary creatinine (UCr, $\mu \mathrm{mol} / \mathrm{l}$ ) assaying was collected. At these times, blood samples were also collected to assess plasma sodium $\left(\mathrm{PNa}^{+}, \mathrm{mmol} / \mathrm{l}\right)$ and plasma creatinine ( $\mathrm{PCr}, \mu \mathrm{mol} / \mathrm{l})$ levels. From the data obtained above, the creatinine clearance $(\mathrm{CLcr}=\mathrm{UCr} / \mathrm{PCr} \times \mathrm{UV})$ and the fractional sodium urinary excretion $\left(\mathrm{FENa}^{+}=\mathrm{UNa}^{+} \mathrm{x}\right.$ $\mathrm{PCr} / \mathrm{PNa}^{+} \mathrm{x} \mathrm{UCr}$ ) were calculated. During these periods, the hemodynamic values, heart rate (HR), mean arterial pressure (MAP) and central venous pressure $(\mathrm{CVP})$ were measured every 30 minutes.

The results are presented as mean and standard deviation. For statistical analysis, the Student t test was used, with $\mathrm{p}<0.05$ as the significance level.

............ RESULTS

A total of 22 adult patients of both genders (9 men and 13 women) were studied, with a mean age of 55.45 years (Table 1 ). The APACHE score results and diagnoses upon admission to the intensive care unit are presented in Tables 2 and 3, respectively. The data collected and presented in Tables 4 and 5 show that there were no significant variations in $\mathrm{HR}, \mathrm{MAP}$ and CVP during the three periods studied.

The individual values for serum creatinine, creatinine clearance, fractional sodium excretion and diuresis for the three periods are presented in Table 6. During the P2 period, during LDD infusion, there was a significant increase in the diuresis volume, in comparison with the P1 and P3 periods (Table 7 and Figure 1). No significant variations in CLcr or $\mathrm{FENa}^{+}$(Table 7) were recorded during the periods studied.

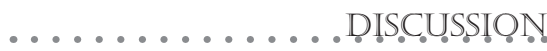

Since dopamine was first synthesized in 1910 , a large amount of research related to this drug has allowed identification of its effects and mechanism of action, $, 2,8,20$ and also definition of its therapeutic possibilities. The idea that LDD could prevent acute renal failure arose naturally from knowledge of its selective renal vasodilatory properties. Acute renal failure is characterized by increased plasma creatinine levels and decreased glomerular filtration rate. This syndrome has a high mortality rate, which justifies the interest in its prevention.

The hemodynamic effects from the infusion of increasing doses of dopamine have been studied by D'Orio et al. (1984). ${ }^{20}$ These authors found that the activity of this agent on 


\begin{tabular}{|c|c|c|c|c|c|c|c|c|c|}
\hline \multirow[t]{2}{*}{ Patients } & \multicolumn{3}{|c|}{ Mean arterial pressure $(\mathrm{mmHg})$} & \multicolumn{3}{|c|}{ Heart rate (bpm) } & \multicolumn{3}{|c|}{ Central venous pressure $(\mathrm{mmHg})$} \\
\hline & P1 & P2 & P3 & P1 & P2 & P3 & P1 & $\mathbf{P 2}$ & P3 \\
\hline AWG & 110 & 100 & 97 & 94 & 121 & 110 & 14.0 & 10.0 & 12.0 \\
\hline LTC & 70 & 80 & 70 & 109 & 105 & 114 & 14.0 & 15.0 & 14.0 \\
\hline NSA & 75 & 95 & 90 & 77 & 87 & 87 & 11.0 & 11.0 & 11.0 \\
\hline $\mathrm{AO}$ & 70 & 80 & 75 & 81 & 93 & 77 & 15.0 & 12.0 & 13.0 \\
\hline JRP & 60 & 70 & 60 & 118 & 122 & 119 & 8.0 & 11.0 & 14.0 \\
\hline EMG & 85 & 85 & 80 & 103 & 102 & 101 & - & - & - \\
\hline ONO & 90 & 90 & 95 & 74 & 73 & 79 & - & - & - \\
\hline AR & 110 & 110 & 100 & 95 & 85 & 76 & 8.0 & 8.0 & 8.0 \\
\hline AV & 92 & 104 & 116 & 99 & 90 & 90 & 11.0 & 11.0 & 11.0 \\
\hline SBR & 100 & 112 & 111 & 81 & 82 & 108 & 8.5 & 9.0 & 9.0 \\
\hline EM & 97 & 99 & 96 & 88 & 96 & 90 & 9.0 & 10.0 & 10.0 \\
\hline JG & 90 & 87 & 80 & 94 & 98 & 95 & 14.0 & 13.0 & 15.0 \\
\hline wo & 87 & 90 & 80 & 105 & 100 & 103 & 11.0 & 10.0 & 11.0 \\
\hline ECS & 106 & 106 & 100 & 100 & 93 & 97 & 10.0 & 15.0 & 15.0 \\
\hline MO & 96 & 90 & 77 & 120 & 120 & 115 & 16.0 & 14.0 & 15.0 \\
\hline AGA & 86 & 87 & 91 & 86 & 87 & 91 & 12.0 & 12.0 & 12.5 \\
\hline LAP & 93 & 87 & 97 & 105 & 102 & 104 & 12.0 & 11.0 & 11.5 \\
\hline $\mathrm{JB}$ & 110 & 100 & 110 & 91 & 93 & 92 & 13.0 & 14.0 & 13.0 \\
\hline RZM & 95 & 97 & 110 & 115 & 135 & 140 & 17.0 & 17.5 & 15.0 \\
\hline GCA & 95 & 110 & 90 & 85 & 92 & 105 & 15.0 & 13.0 & 15.0 \\
\hline $\mathrm{FCB}$ & 85 & 95 & 90 & 96 & 100 & 95 & 15.0 & 13.0 & 13.5 \\
\hline MHA & 76 & 73 & 80 & 77 & 87 & 84 & 17.0 & 17.5 & 17.5 \\
\hline
\end{tabular}

$\beta 1$ receptors was reflected in improved cardiac output, while stimulation of $\alpha 1$ receptors led to increased systemic arterial pressure. They furthermore concluded that, at doses equal to or smaller than $2 \mu \mathrm{g} / \mathrm{kg} / \mathrm{min}$, dopamine has selective action on the dopaminergic receptors. Stimulation of $\beta 1$ receptors can be perceived at doses as small as $3 \mu \mathrm{g} / \mathrm{kg} / \mathrm{min}$.

Among the patients of the present study, no significant variations in $\mathrm{HR}, \mathrm{CVP}$ or MAP were observed, which is in agreement with various other studies. Indeed, LDD seems to have no cardiac effects. In patients at the postoperative stage of cardiac surgery, Sato et al. $(1982)^{21}$ detected that LDD had a favorable effect on renal hemodynamics, without changing the cardiac output. Similar results were achieved by Lherm et al. (1996) ${ }^{11}$ in patients with septic syndrome and septic shock. Strigle \& Petrinec (1990), ${ }^{22}$ in an experimental model, did not detect pressure changes in the systemic or pulmonary occluded arteries.

With regard to renal function, many studies undertaken among normal individuals or patients with different diagnoses have shown a beneficial effect. Some previous studies,
Table 5. Hemodynamic analysis of 22 patients admitted in an intensive care unit in São Paulo during the three phases of the study (P1, P2, and P3)

\begin{tabular}{lccc} 
Variable & P1 & P2 & P3 \\
\hline Heart rate $(\mathrm{bpm})$ & $95.1 \pm 13.43$ & $98.3 \pm 14.86$ & $98.7 \pm 15.33$ \\
Arterial pressure $(\mathrm{mmHg})$ & $89.9 \pm 13.63$ & $93.0 \pm 11.66$ & $90.7 \pm 14.41$ \\
\hline Central venous pressure $(\mathrm{mmHg})$ & $12.5 \pm 2.91$ & $12.4 \pm 2.60$ & $12.8 \pm 2.38$ \\
\hline
\end{tabular}

Results are expressed in mean \pm standard deviation.

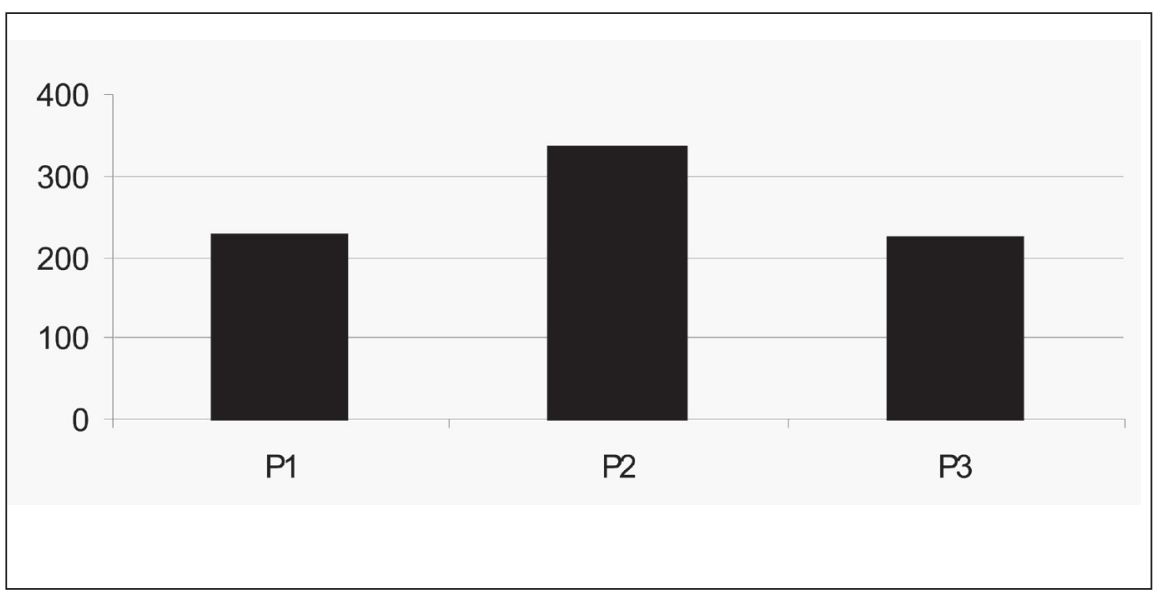

Figure 1. Diuresis (in $\mathrm{ml}$ ) during the three infusion periods (P1, P2, and P3) in 22 patients admitted in na intensive care unit in São Paulo. Results are expressed in means. 
and even more recent ones, have shown an improvement in renal function in a variety of settings, such as situations of high intra-abdominal pressure during laparoscopy, ${ }^{23}$ cardiac surgery, ${ }^{24,25}$ refractory ascites due to cirrhosis, ${ }^{26}$ liver transplantation, ${ }^{27}$ general intensive care $^{28,29}$ or postoperative states. Some authors have even suggested that the responsiveness to LDD, as assessed by two-hour creatinine clearance, could be helpful in selecting patients who would benefit from its use. ${ }^{30}$ Although these studies have shown beneficial effects, most of them only included small numbers of patients and did not evaluate the long term effects of LDD. In a recent study, LDD was found to increase creatinine clearance, diuresis and fractional sodium excretion, without concomitant hemodynamic change. These effects reached a maximum during an eighthour period of LDD infusion. But despite the persistence of a slight increase in diuresis, the improvement in creatinine clearance and $\mathrm{FENa}^{+}$disappeared after 48 hours. ${ }^{28}$ According to these data, it is likely that tolerance to dopamine-receptor agonists develops in critically ill patients.

However, this beneficial effect has not been consistently confirmed by other authors. Even the short-term effects of LDD were not confirmed by the present study, in which no differences in creatinine clearance were found. Corroborating our results, other authors have also shown that renal function is not improved with LDD for patients undergoing cardiac surgery ${ }^{16}$ or liver transplantation, ${ }^{17}$ or for those in postoperative states, ${ }^{15,16,31}$ critically ill with oliguria, ${ }^{13}$ or with previous renal diseases. ${ }^{14}$ Other recent studies have confirmed these findings. In a double-blind, randomized, multicenter, placebo-controlled study with a large number of severely ill patients $(\mathrm{n}=$ 328), ${ }^{18}$ treatment with LDD did not seem to be advantageous. Patients with at least two systemic inflammatory response syndrome criteria and evidence of early renal dysfunction (oliguria or increased serum creatinine levels) did not present any protective effect, as assessed by peak creatinine levels. There was no difference in the evolution and severity of renal dysfunction, or in the length of hospital or intensive care unit stay. ${ }^{18}$ Although this is the

\begin{tabular}{|c|c|c|c|c|c|c|c|c|c|c|c|c|}
\hline \multirow[t]{2}{*}{ Patients } & \multicolumn{3}{|c|}{ Serum creatinine $(\mathrm{mg} / \mathrm{dl})$} & \multicolumn{3}{|c|}{ Creatinine clearance $(\mathrm{ml} / \mathrm{min})$} & \multicolumn{3}{|c|}{ Fraction of sodium excretion } & \multicolumn{3}{|c|}{ Diuresis (ml) } \\
\hline & P1 & P2 & P3 & P1 & P2 & P3 & $\mathbf{P 1}$ & $\mathbf{P 2}$ & P3 & P1 & P2 & P3 \\
\hline AWG & 0.8 & 0.7 & 0.5 & 142.3 & 168.9 & - & 0.666 & 1.350 & - & 112 & 346 & 86 \\
\hline LTC & 0.9 & 0.9 & 0.9 & 155.8 & 87.1 & 87.0 & 1.079 & 0.756 & - & 306 & 147 & 336 \\
\hline NSA & 0.6 & 0.6 & 0.6 & 166.1 & 218.8 & 165.0 & 2.033 & 2.128 & 2.700 & 427 & 525 & 463 \\
\hline $\mathrm{AO}$ & 0.6 & 0.5 & 0.6 & 118.8 & 129.1 & 297.0 & 0.142 & 0.829 & 0.132 & 186 & 352 & 320 \\
\hline JRP & 1.1 & 1.1 & 1.2 & 139.1 & 298.1 & 63.0 & 0.656 & 0.853 & 1.376 & 102 & 305 & 114 \\
\hline EMG & 0.9 & 0.9 & 0.8 & 172.5 & 147.5 & 74.0 & 1.259 & 1.387 & 1.451 & 207 & 175 & 217 \\
\hline ONO & 1.0 & 0.9 & 1.0 & 69.6 & 162.7 & 171.0 & 1.620 & 0.996 & 2.593 & 522 & 676 & 542 \\
\hline AR & 1.7 & 1.6 & 1.9 & 133.6 & 240.0 & 127.0 & 0.177 & 0.276 & 0.374 & 213 & 388 & 235 \\
\hline AV & 1.3 & 1.2 & 1.2 & 208.0 & 250.0 & 179.0 & 0.500 & 0.300 & 0.700 & 200 & 250 & 220 \\
\hline SBR & 0.7 & 0.5 & 0.6 & 171.0 & 135.0 & 54.0 & - & 0.900 & 3.000 & 70 & 200 & 210 \\
\hline EM & 0.8 & 0.5 & 0.6 & 231.0 & 230.0 & 194.0 & 0.700 & 1.100 & 1.100 & 250 & 300 & 250 \\
\hline JG & 1.0 & 1.2 & 1.2 & 116.5 & 67.2 & 49.0 & 0.919 & 0.759 & 0.901 & 190 & 220 & 100 \\
\hline wo & 0.6 & 0.6 & 0.6 & 87.5 & 152.0 & 101.2 & 0.787 & 0.565 & 0.250 & 180 & 240 & 185 \\
\hline ECS & 0.6 & 0.5 & 0.6 & 309.2 & 145.1 & 90.1 & 1.370 & 0.352 & 1.222 & 305 & 55 & 102 \\
\hline MO & 0.6 & 0.7 & 0.7 & 110.6 & 138.3 & 107.4 & 1.915 & 2.333 & 0.747 & 325 & 440 & 160 \\
\hline AGA & 0.7 & 0.8 & 0.9 & 161.1 & 65.3 & 41.2 & 3.561 & 7.601 & 1.918 & 410 & 352 & 80 \\
\hline LAP & 0.7 & 0.7 & 0.7 & 275.4 & 149.6 & 104.1 & 0.363 & 1.365 & 2.160 & 120 & 245 & 270 \\
\hline $\mathrm{JB}$ & 0.8 & 0.9 & 0.9 & 51.6 & 85.6 & 115.9 & 1.526 & 1.691 & 1.538 & 110 & 560 & 400 \\
\hline RZM & 0.6 & 0.6 & 05 & 129.2 & 197.2 & 96.3 & 0.818 & 1.024 & 0.587 & 150 & 355 & 105 \\
\hline GCA & 1.1 & 0.8 & 0.9 & 75.0 & 134.4 & 63.9 & 0.278 & 0.812 & 0.451 & 132 & 645 & 115 \\
\hline $\mathrm{FCB}$ & 0.7 & 0.7 & 0.6 & 141.7 & 65.0 & 232.5 & 0.763 & 0.542 & 0.393 & 350 & 455 & 310 \\
\hline MHA & 0.8 & 0.7 & 0.8 & 108.3 & 116.4 & 108.9 & 0.233 & 0.184 & 0.225 & 92 & 115 & 95 \\
\hline
\end{tabular}

\begin{tabular}{|c|c|c|c|c|}
\hline \multicolumn{5}{|c|}{$\begin{array}{l}\text { Table 7. Renal function of } 22 \text { patients admitted in an intensive care unit } \\
\text { in São Paulo during the three phases of the study (P1, P2, and P3) }\end{array}$} \\
\hline Variable & P1 & P2 & P3 & $\mathbf{p}$ \\
\hline Diuresis (ml) & $225.40 \pm 122.70$ & $333.90 \pm 165.3$ & $223.4 \pm 129.4$ & $<0.05$ \\
\hline Clearance of creatinine $(\mathrm{ml} / \mathrm{min})$ & $148.80 \pm 63.30$ & $153.80 \pm 63.60$ & $120.10 \pm 65.20$ & ns \\
\hline Fraction of sodium excretion & $1.0 \pm 0.8$ & $1.3 \pm 1.5$ & $1.2 \pm 0.8$ & ns \\
\hline
\end{tabular}

Results are expressed in mean \pm standard deviation. $n s=$ not significant. 
largest study performed to assess this question, one possible bias to be taken into account is the lack of control over the volemic resuscitation rate. The possible effect of administering other drugs that could potentially affect renal perfusion or diuresis also needs to be considered. ${ }^{18}$ In a recently published meta-analysis including 970 patients, no improvement in serum creatinine levels or the incidence of renal function were detected. ${ }^{32}$ The same conclusion was reached in a recently published review on this subject. ${ }^{33}$

When analyzing the renal effects of LDD, a distinction must be made between increased diuresis and the biochemical improvement of renal function. It is important to take into account that there is no clearly direct relationship between these two variables, and that excessive diuresis may be harmful. With LDD infusion, the patients in the present study showed a significant increase in diuresis, of $48 \%$, which corroborates the findings of other researchers. ${ }^{12,17,27,34-37}$ Although some of these authors argue that a significant increase in diuresis after LDD infusion could protected the kidney, for instance against the hazardous effects of crossclamping of the aorta, ${ }^{35}$ there is no strong evidence that this really occurs. Nonetheless, despite the increased diuresis, our patients did not have a corresponding increase in CLcr. This therefore suggests the absence of a direct consistent relation between CLcr and diuresis. Thus, dopamine seems to have no beneficial effects and may increase diuresis, with the potential risk of jeopardizing the patient's volemic state. This is potentially deleterious in critically ill patients, for whom hypovolemic states must be avoided as a general rule. Moreover, among patients with mild to moderate renal failure or diabetes mellitus undergoing coronary angiography and receiving contrast, LDD seemed to have no advantage over volume replacement in preventing acute renal failure. ${ }^{38}$

It is therefore questionable whether renal function can be improved by the use of LDD, although increased diuresis is likely to occur, at least in some patients, as shown in our study. Thus, the question to be answered is whether it is better to use LDD or other diuretics when the objective is to increase diuresis. One potential benefit of LDD is its more continuous and homogeneous effect, which could be indicated in some clinical situations. However, although we could not demonstrate any cardiovascular effects from LDD, there is a potential concern about using a vasoactive drug instead of a diuretic when the desired effect is to increase urine output. In preeclampsia/eclampsia patients with persistent oliguria after adequate volume replacement, LDD was similar in effect to furosemide, in relation to diuresis improvement and the need for hemodialysis. ${ }^{39}$ Although there has not yet been any definitive answer to this question, it seems that LDD is not superior to diuretics.

Another aspect that needs to be assessed is the potential effect of LDD on sodium metabolism. The effect of LDD on natriuresis may be explained by its inhibition of aldosterone, ${ }^{14}$ and by its direct action on the proximal renal tubules. ${ }^{10}$ In some studies in which a significant increase in sodium excretion was detected, the patients were suffering from congestive cardiac failure, ${ }^{4,12}$ but other studies have found higher excretion even in patients without cardiac disease. ${ }^{28,37}$ It has been suggested that the action of aldosterone (commonly found at high rates in congestive cardiac failure) would be antagonized by the action of LDD on the DA2 receptors, thereby increasing diuresis and the output of $\mathrm{Na}^{+}{ }^{2}$ This matter continues to be controversial, since other authors have failed to detect this effect. ${ }^{4,9,17,40}$ In the present investigation the increase in $\mathrm{FENa}^{+}(30 \%)$ was not considered significant.

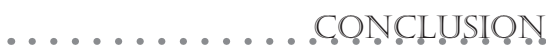

We have shown that the infusion of $2 \mu \mathrm{g} /$ $\mathrm{kg} / \mathrm{min}$ of dopamine for two hours increased the diuresis but did not changed CLcr and $\mathrm{FENa}^{+}$. This is in agreement with many other studies on humans that have not demonstrated the prevention of acute renal failure in highrisk patients or an improved outcome for those with established acute renal failure. We did not find any cardiovascular effects from LDD. However, while the safety profile of LDD in these settings has not been extensively defined, it is known that dopamine may precipitate serious cardiovascular and metabolic complications in critically ill patients. As the use of dopamine seems to have no beneficial effects and may increase diuresis, with a potential for compromising the patient's volemic state, its use with such indication ought to be avoided in intensive care unit patients. However, in hypervolemic patients, dopamine use may be considered. We suggest that LDD should not be used for selective renal vasodilatory and natriuretic actions in patients with acute renal failure until their efficacy has been established in randomized controlled trials. However, the use of dopamine for its systemic effects in heart failure and septic shock should not be precluded, since this may have beneficial effects.
1. Schwartz LB, Gewertz BL. The renal response to low dose dopamine. J Surg Res. 1988;45(6):574-88.

2. Bonde J, Lauritsen HK, Stenberg M, Kamp-Jensen M, Olsen NV. Low-dose dopamine in surgical and intensive care unit patients. Acta Anaesthesiol Scand. 1996;40(3):326-30.

3. Richer M, Robert S, Lebel M. Renal hemodynamics during norepinephrine and low-dose dopamine infusions in man. Crit Care Med. 1996;24(7):1150-6

4. Duke GJ, Bersten AD. Dopamine and renal salvage in the critically ill patient. Anaesth Intensive Care. 1992;20(3):277-87.

5. Denton MD, Chertow GM, Brady HR. "Renal-dose" dopamine for the treatment of acute renal failure: scientific rationale, experimental studies and clinical trials. Kidney Int. 1996;50(1):4-14

6. Carcoana OV, Hines RL. Is renal dose dopamine protective or therapeutic? Yes. Crit Care Clin. 1996;12(3):677-85.

7. Cottee DB, Saul WP. Is renal dose dopamine protective or therapeutic? No. Crit Care Clin. 1996;12(3):687-95.

8. Baldwin L, Henderson A, Hickman P. Effect of postoperative low-dose dopamine on renal function after elective major vascular surgery. Ann Intern Med. 1994;120(9):744-7.

9. Duke GJ, Briedis JH, Weaver RA. Renal support in critically ill patients: low-dose dopamine or low-dose dobutamine? Crit Care Med. 1994;22(12):1919-25.

10. Ramires JA, Tsanaclis A, Gimenez HC, da-Luz PL, Pileggi F. Acute effects of dobutamine and dopamine on renal and respiratory functions in patients on prolonged mechanical ventilation. Braz J Med Biol Res 1991;24(1):35-42.

11. Lherm T, Troché G, Rossignol M, Bordes P, Zazzo JF. Renal effects of low-dose dopamine in patients with sepsis syndrome or septic shock treated with catecholamines. Intensive Care Med. 1996;22(3):213-9.

12. Casson IF, Clayden DA, Cope GF, Lee MR. The protective effect of gamma-glutamyl L-dopa on the glycerol treated rat model of acute renal failure. Clin Sci. 1983;65(2):159-64

13. Henderson IS, Beattie TJ, Kennedy AC. Dopamine hydrochloride in oliguric states. Lancet. 1980;2(8199):827-8.

14. Smit AJ, Meijer S, Wesseling H, Reitsma WD, Donker AJ Impaired renal hemodynamic but conserved natriuretic response to dopamine in patients with renal disease. Nephron. 1989;52(4):338-46.

15. Sandberg J, Tydén G, Groth CG. Low-dose dopamine infusion following cadaveric renal transplantation: no effect on the incidence of ATN. Transplant Proc. 1992;24(1):357.

16. Myles PS, Buckland MR, Schenk NJ, et al. Effect of "renal-dose" dopamine on renal function following cardiac surgery. Anaesth Intensive Care. 1993;21(1):56-61.

17. Swygert TH, Roberts LC, Valek TR, et al. Effect of intraoperative low-dose dopamine on renal function in liver transplant recipients. Anesthesiology. 1991;75(4):571-6.

18. Bellomo R, Chapman M, Finfer S, Hickling K, Myburgh J 
Low-dose dopamine in patients with early renal dysfunction: a placebo-controlled randomised trial. Australian and New Zealand Intensive Care Society (ANZICS) Clinical Trials Group. Lancet. 2000;356(9248):2139-42.

19. Knaus WA, Draper EA, Wagner DP, Zimmerman JE. APACHE II: a severity of disease classification system. Crit Care Med. 1985;13(10):818-29.

20. D'Orio V, el Allaf D, Juchmès J, Marcelle R. The use of low doses of dopamine in intensive care medicine. Arch Int Physiol Biochim. 1984;92(4):S11-20.

21. Sato Y, Matsuzawa H, Eguchi S. Comparative study effects of adrenaline, dobutamine and dopamine on systemic hemodynamics and renal blood flow in patients following open heart surgery. Jpn Circ J. 1982;46(10):1059-72.

22. Strigle TR, Petrinec D. The effect of renal range dopamine and norepinephrine infusions on the renal vasculature. Am Surg. 1990;56(8):494-6.

23. Pérez J, Taurá P, Rueda J, et al. Role of dopamine in renal dysfunction during laparoscopic surgery. Surg Endosc. 2002;16(9):1297-301

24. Sumeray M, Robertson C, Lapsley M, Bomanji J, Norman AG, Woolfson RG. Low dose dopamine infusion reduces renal tubular injury following cardiopulmonary bypass surgery. J Nephrol. 2001;14(5):397-402

25. Melchiorre C, Quaglia W, Picchio MT, Giardinà D, Brasili L, Angeli P. Structure-activity relationships among methoctraminerelated polymethylene tetraamines. Chain-length and substitu- ent effects on M-2 muscarinic receptor blocking activity. J Med Chem. 1989;32(1):79-84.

26. Lin SM, Lee CS, Kao PF. Low-dose dopamine infusion in cirrhosis with refractory ascites. Int J Clin Pract. 1998;52(8):533-6.

27. Polson RJ, Park GR, Lindop MJ, Farman JV, Calne RY, Williams $\mathrm{R}$. The prevention of renal impairment in patients undergoing orthotopic liver grafting by infusion of low dose dopamine. Anaesthesia. 1987;42(1):15-9.

28. Ichai C, Passeron C, Carles M, Bouregba M, Grimaud D. Prolonged low-dose dopamine infusion induces a transient improvement in renal function in hemodynamically stable, critically ill patients: a single-blind, prospective, controlled study. Crit Care Med. 2000;28(5):1329-35.

29. Ichai C, Soubielle J, Carles M, Giunti C, Grimaud D. Comparison of the renal effects of low to high doses of dopamine and dobutamine in critically ill patients: a single-blind randomized study. Crit Care Med. 2000;28(4):921-8.

30. Eachempati SR, Reed RL. Use of creatinine clearances to monitor the effect of low-dose dopamine in critically ill surgical patients. J Surg Res. 2003;112(1):43-8.

31. Bryan AG, Bolsin SN, Vianna PT, Haloush H. Modification of the diuretic and natriuretic effects of a dopamine infusion by fluid loading in preoperative cardiac surgical patients. J Cardiothorac Vasc Anesth. 1995;9(2):158-63.

32. Power DA, Duggan J, Brady HR. Renal-dose (low-dose) dopamine for the treatment of sepsis-related and other forms of acute renal failure: ineffective and probably dangerous. Clin Exp
Pharmacol Physiol Suppl. 1999;26:S23-8.

33. Marik PE. Low-dose dopamine: a systematic review. Intensive Care Med. 2002;28(7):877-83.

34. Flancbaum L, Choban PS, Dasta JF. Quantitative effects of low-dose dopamine on urine output in oliguric surgical intensive care unit patients. Crit Care Med. 1994; 22(1):61-8.

35. Salem MG, Crooke JW, McLoughlin GA, Middle JG, Taylor WH. The effect of dopamine on renal function during aortic cross clamping. Ann R Coll Surg Engl. 1988;70(1):9-12.

36. Girbes AR, Patten MT, McCloskey BV, Groeneveld AB, Hoogenberg $\mathrm{K}$. The renal and neurohumoral effects of the addition of low-dose dopamine in septic critically ill patients. Intensive Care Med. 2000;26(11):1685-9.

37. Benmalek F, Behforouz N, Benoist JF, et al. Renal effects of low-dose dopamine during vasopressor therapy for posttraumatic intracranial hypertension. Intensive Care Med. 1999;25(4):399-405.

38. Gare M, Haviv YS, Ben-Yehuda A, et al. The renal effect of low-dose dopamine in high-risk patients undergoing coronary angiography. J Am Coll Cardiol. 1999;34(6):1682-8.

39. Keiseb J, Moodley J, Connolly CA. Comparison of the efficacy of continuous furosemide and low-dose dopamine infusion in preeclampsia/eclampsia-related oliguria in the immediate postpartum period. Hypertens Pregnancy. 2002;21(3):225-34.

40. Dick M, Dasta JF, Choban PS, Sinha R, Flancbaum L. Serum aldosterone concentrations and urine output in oliguric intensive care unit patients receiving low-dose dopamine. Ann Pharmacother. 1994, 28(7-8):837-41.

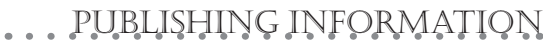

Cláudia Nathalie Pereira, MD. Fellow. Intensive Care Unit, Discipline of Anesthesiology, Pain and Intensive Care, Universidade Federal de São Paulo, São Paulo, Brazil.

Flávia Ribeiro Machado, MD, PhD. Head of clinic. Intensive Care Unit, Discipline of Anesthesiology, Pain and Intensive Care, Universidade Federal de São Paulo, São Paulo, Brazil.

Hélio Penna Guimarães, MD. Attending doctor. Intensive Care Unit, Discipline of Anesthesiology, Pain and Intensive Care, Universidade Federal de São Paulo, São Paulo, Brazil.

Ana Paula Resque Senna, MD. Attending doctor. Intensive Care Unit, Discipline of Anesthesiology, Pain and Intensive Care, Universidade Federal de São Paulo, São Paulo, Brazil.

José Luiz Gomes do Amaral, MD, PhD. Head of clinic. Intensive Care Unit, Discipline of Anesthesiology, Pain and Intensive Care, Universidade Federal de São Paulo, São Paulo, Brazil.

\section{Sources of funding: None \\ Conflict of interest: None \\ Date of first submission: February 27, 2003 \\ Last received: November 6, 2003 \\ Accepted: March 15, 2004}

\author{
Address for correspondence: \\ José Luiz Gomes do Amaral \\ Disciplina de Anestesiologia, Dor e Terapia Intensiva \\ - Universidade Federal de São Paulo \\ Rua Botucatu, 740 - Vila Clementino \\ São Paulo (SP) - Brasil - CEP 04024-900 \\ Tel. (+55 11) 5576-4069 \\ E-mail:ilgamaral@uol.com.br
}

COPYRIGHT @ 2004, Associação Paulista de Medicina

REESUMMOQ

Função renal e hemodinâmica durante a administração de dopamina em doses baixas em pacientes gravemente enfermos

CONTEXTO: Apesar do grande número de trabalhos sobre os efeitos renais e hemodinâmicos de doses baixas de dopamina em pacientes graves, ainda existe muita controvérsia a respeito.

OBJETIVOS: Esse estudo objetivou avaliar os efeitos de dopamina ( $2 \mathrm{mcg} / \mathrm{kg} / \mathrm{min})$ na hemodinâmica (máxima pressão arterial média, PAM, freqüência cardíaca máxima, FR, pressão venosa central, PVC, clearance de creatinina, CLcr, diurese e fração de excreção de sódio, $\mathrm{FENa}^{+}$).

TIPO DE ESTUDO: Estudo clínico não randomizado, aberto, prospectivo.

LOCAL: Uma unidade de terapia intensiva em hospital universitário terciário.

PARTICIPANTES: 22 pacientes com estabilidade hemodinâmica admitidos na Unidade.

PROCEDIMENTOS: Os pacientes foram submetidos a três períodos de duas horas de duração cada um: sem dopamina (P1), com dopamina (P2) e sem dopamina (P3).

PRINCIPAIS VARIÁVEIS ESTUDADAS: As variáveis acima mencionadas foram medidas em cada um dos períodos. CLcr foi medido baseado na fórmula U.V/P, onde $\mathrm{U}$ é a creatinina urinária $(\mathrm{mg} / \mathrm{dl}), \mathrm{V}$ é a diurese em $\mathrm{ml} / \mathrm{min}$ e $\mathrm{P}$ é a creatinina sérica $(\mathrm{mg} / \mathrm{dl})$. $\mathrm{FENa}^{+}$foi calculado baseado na fórmula: sódio urinário $(\mathrm{mEq} / \mathrm{l}) \times \mathrm{P} /$ sódio plasmático $(\mathrm{mEq} / \mathrm{l}) \times \mathrm{U}) \times 100$. Os resultados foram apresentados como média e desvio padrão. $\mathrm{O}$ teste t de Student foi utilizado e os resultados considerados significativos se o valor de $\mathrm{p}$ fosse menor que 0,05 .

RESULTADOS: 12 pacientes (sete homens e cinco mulheres) foram incluídos, com a idade média de 55.45 anos. Não houve nenhuma variação na PAM, FR, PVC, CLcr ou FENa ${ }^{+}$com o uso de dopamina na dose de $2 \mathrm{mcg} / \mathrm{kg} / \mathrm{min}$. Entretanto, a diurese aumentou significativamente no $\mathrm{P} 2$, de 225.4 para $333.9 \mathrm{ml}$.

CONCLUSÕES: A infusão de $2 \mathrm{mcg} / \mathrm{kg} / \mathrm{min}$ de dopamina durante duas horas aumenta a diurese. Nas doses estudadas, a dopamina não induziu alteraçōes significativas na PAM, FR, PVC, CLcr e FENa ${ }^{+}$.

PALAVRAS-CHAVE: Dopamina. Processos hemodinâmicos. Unidades de Terapia Intensiva. Diurese. Diuréticos. 